\author{
R. Boukarm ${ }^{1,3}$, \\ A. Houam ${ }^{2}$, Dr. Sc. (Tech.), Prof., \\ M. Fredj ${ }^{3}$, \\ R. Boucif ${ }^{3}$
}

1 - Laboratory of Construction Engineering and Architecture (LGCA), Faculty of Technology, University of Bejaia, Bejaia, Algeria, e-mail: boulkram@gmail.com

2 - King Khalid University, College of Engineering, Civil Department, Guraiger, Abha, Kingdom of Saudi Arabia

3 - Mining and Geology Department, Faculty of Technology, University of Bejaia, Bejaia, Algeria

\title{
GEOTECHNICAL RISK ASSESSMENT OF ROCK SLOPE STABILITY USING NON-LINEAR STRENGTH CRITERION
}

Purpose. To assess the geotechnical risk of rock slope stability by empirical, numerical and Limit Equilibrium methods with the generalized Hoek-Brown criterion as a strength failure criterion to encompass all structural and geomechanical parameters influencing the stability of the open slope.

Methodology. The study conducted risk assessment in three steps: risk identification, risk analysis, and risk evaluation. First, site observation and movement monitoring confirmed the real existence of instability risk. Then, from the in situ and laboratory investigations, an empirical classification called Slope Mass Rating, SMR and a geotechnical model were obtained. Finally, a quantification of this risk was evaluated using the limit equilibrium method and the finite difference method while considering the nonlinear criterion of Hoek-Brown as a criterion of failure.

Findings. The non-linear generalized Hoek-Brown criterion can be used with some reliability in these stability studies since it takes into account the conditions of the discontinuities and the rate of fracturing within the rock mass.

Originality. The method for geotechnical risk management was used based on the application of different approaches to quantify the geotechnical risk induced by the exploitation of this open pit. To attain the objective, the following techniques were involved: rock mass classification, geological strength index, limit equilibrium analysis. The philosophy of the research implies combining geometrical, structural and mechanical parameters to assess the rock slope stability

Practical value. This work has allowed us to conclude that SMR classification can be used as a prior check taking into account the structural and geometric context of the rock mass (orientation and integrity damage conditions, fracturing rates). The values of the safety factors of the extended Janbu's method and that of Morgenstern \& Price are quite close to the method of finite differences (use of shear strength reduction technique)

Keywords: rock mass classification, rock quality designation, geological strength index, Hoek-Brown generalized model, safety factor

Introduction. The study of rock slope stability is a classical problem in the geotechnical engineering. The rock slope instabilities in the mining area are often spectacular and sudden with dramatic consequences resulting in the economic challenge.

The assessment of the rock slope stability can be carried out either by empirical, equilibrium or numerical methods $[1-3]$. Rock mass classification is a means for the evaluation of the performance of rock cut slopes based on the most important inherent and structural parameters. Most of the classification systems proposed worldwide provide a consistent means of describing rock mass condition quantitatively [4].

Among these methods, we can distinguish Rock Mass Rating (RMR) [5], Slope Mass Rating SMR [6] and Geological Strength Index $(G S I)$ [7] which are used in rock slope stability analysis [8].

In geotechnical point of view, the design methods for rock slopes are divided into two groups [9]: limit equilibrium analysis (LEA) and numerical analysis. Methods of limit equilibrium are widely used in the geotechnical engineering; they give faster results but present shortcomings, in particular, regarding the choice of slip surface (necessity to specify slip surface). However, numerical methods can overcome these drawbacks through the shear strength reduction technique $[10,11]$.

The Mohr-Coulomb rupture criterion is one of the most used criteria in the analysis of slope stability; it is a linear criterion characterized by 2 plastic parameters (cohesion and angle internal friction). Hoek and Brown developed an empirical criterion, which represents the nonlinearity observed in rock mass behavior in experiments of rocks. The generalized Hoek-Brown criterion [12] takes into account the degree of fracturing, rock mass disturbance of and GSI.

The Kef Essenoun mine is part of the Djebel El-Onk phosphate deposit located in southeastern Algeria, which rep-

(C) Boukarm R., Houam A., Fredj M., Boucif R., 2019 resents more than half of Algeria's phosphate reserves. Since 2013, cracks and fractures have appeared along the west flank of Kef Essenoun predicting a potential risk of sliding. The company SOMIPHOS undertook studies to evaluate the state of stability along the west embankment.

The aim of our work is to assess the risk of Kef Essenoun open pit by empirical, numerical and Limit Equilibrium methods with the generalized Hoek-Brown criterion used as a strength failure criterion to encompass all structural and geomechanical parameters influencing the stability of the open slope.

Methods. Appearance of cracks and fissuration can be considered as instability indicators. Subsequently, deep investigations must be carried out: in situ and laboratory measurements, through structural data and historical events, in order to obtain an accurate geotechnical model.

Our objective is to evaluate the geotechnical risk associated with Kef Essenoun open pit through a comparative assessment of slope stability taking in account inherent parameters of the geotechnical model by the empirical method (Slope Mass Rating), Limit Equilibrium methods and finite difference method.

This assessment involves three main steps, namely risk identification, risk analysis and finally risk evaluation based on a pre-established decision criterion (Fig. 1).

Risk Identification. Geological Perspective. The Djebel El Onk deposit is in the south of Tébessa province (northeast of Algeria) (Fig. 2, a) about $21 \mathrm{~km}$ to the Algerian-Tunisian frontiers. The phosphate deposits of the Djebel El-Onk region is divided into five mining districts (Consultant BRGM - SOFREMINES 1992: Djemi-Djema, Djebel El-Onk North, Bled El Hadba, Oued Betita and Kef Essenoun. It represents more than half of the Algerian phosphate reserves. Kef Essenoun is located in the extension of the southern Cretaceous anticline of Djebel ElOnk. The Kef Essenoun deposit is one of the largest, with a power of 35 to $40 \mathrm{~m}$ of phosphate without intercalation of waste rock.

The Kef Essenoun deposit is made up from the bottom up by the following lithological successions (Fig. 2, $b$ ): 


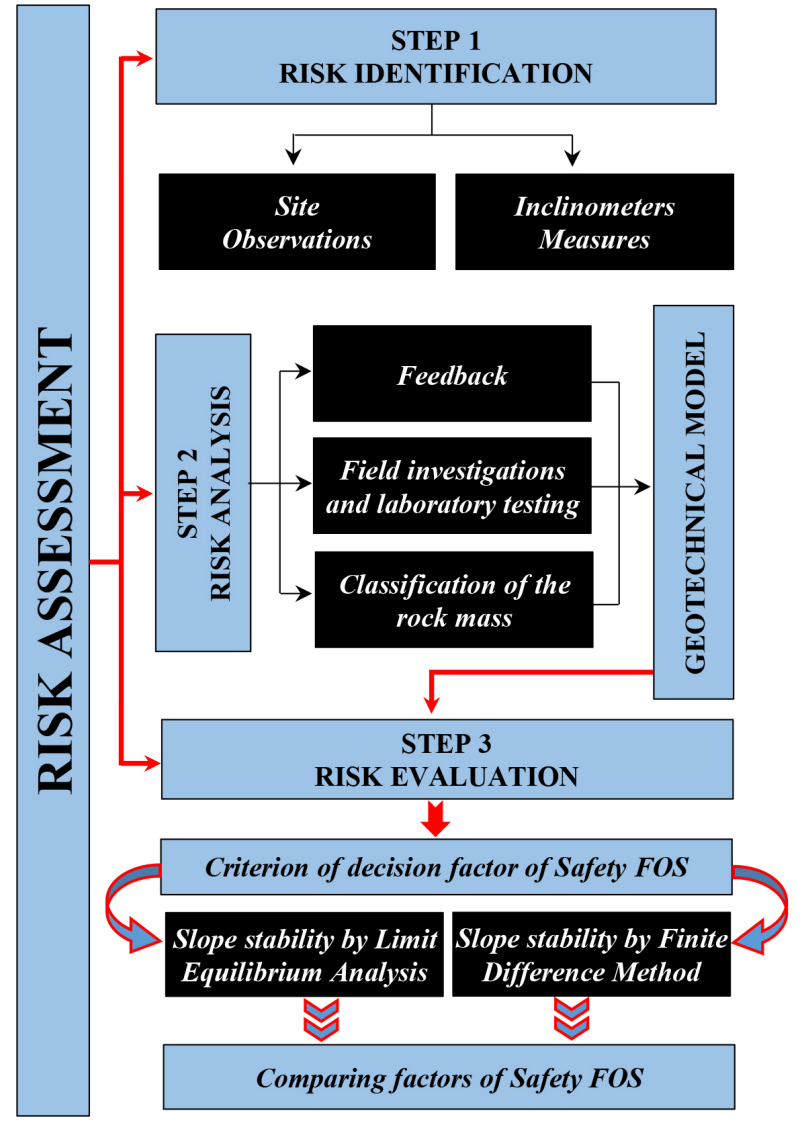

Fig. 1. Flowchart of assessment of Kef Essenoun open pit stability

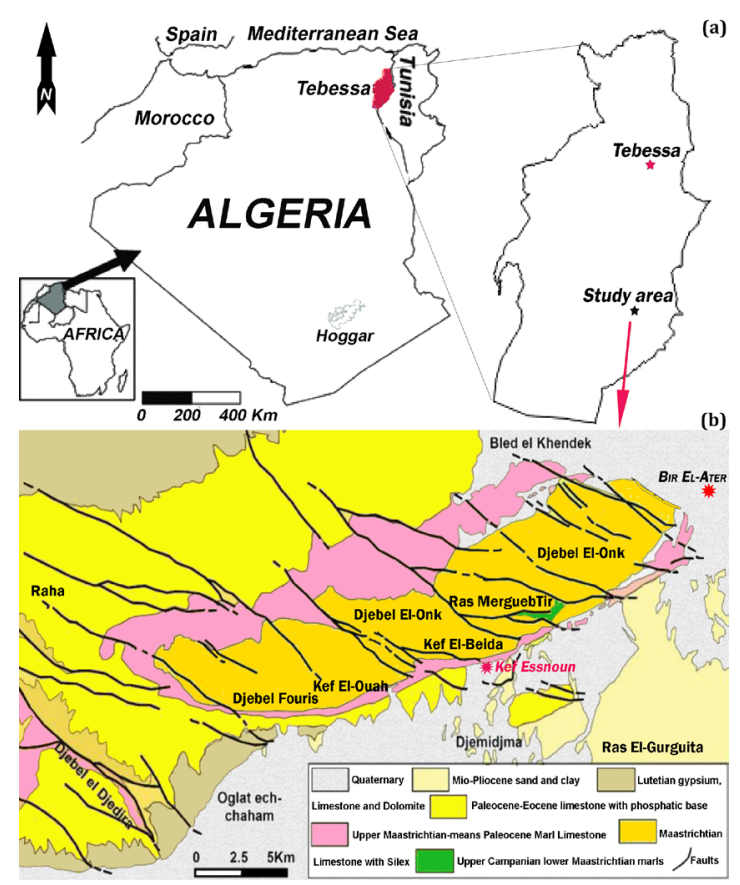

Fig. 2. Location map and geological area of Kef Essenoun open pit

- formations of the lower Thanetian (the wall of the phosphate beam) are represented by laminated marls;

- the phosphate bundle belonging to the upper Thanetian is constituted by a single layer of phosphate without sterile intercalation;

- at the roof of the phosphate beam, the calcareous-dolomitic silex series of the Ypresian appears, above which the Lutetian limestone is deposited locally, then the Miocene sands and lastly the recent Quaternary deposits consisting essentially of alluvial deposits. The total thickness of the sterile covering varies from $40 \mathrm{~m}$ in the north to $198 \mathrm{~m}$ in the south.

The pit is excavated as benches with slope angles of 75 to $85^{\circ}, 15 \mathrm{~m}$ high, and $10 \mathrm{~m}$ wide. The depth of the base of mine is $90 \mathrm{~m}$.

Site observations and inclinometer's measures. Regular and continuous field monitoring allows the detection of every anomaly whose consequences could be catastrophic for the technical and economic future of a mine. Generally, visual inspection, inclinometers, and laser scanning are widely used in this field of detection and control.

In order to try to understand and measure the extent of cracks observed since 2013, SOMIPHOS carried out a reconnaissance and investigation campaign punctuated by on-site observations (Fig. 3) and the installation of 2 inclinometers in order to control and monitor the evolution of these fractures.

In addition to the visual observations, analysis of different recordings on inclinometers at different dates indicates the great extent of the propagation of these cracks and consequently leads us to making in-depth analyzes (Fig. 4). Nouioua 2015 [13] concludes that the geometry and evolution of the underground cracks are probably caused by recent landslides.

Risk analysis. Feedback. Historical events and back analysis can bring more important information on the causes, mechanisms and mechanical parameters relating to sliding which occurred in the field. In September 2007 a landslide occurred in the Northeast flank of the Kef Essenoun phosphate deposit (Fig. 5) during which a mass of rocks estimated at 7.7 million $\mathrm{m}^{3}$ detached and filled the pit. Expertise and several investigations were carried out; Gadri [14] concluded that the failure mode was a planar sliding, which occurred along the layer of altered marls.

In our approach, since the failure was induced by the marl layer, the slip plan mode will be taken into account as a starting hypothesis.

Field investigations and laboratory testing. The characterization and classification of a massif involve the observation and recording of structural surveys through different homogenous outcrops, which are supposed to represent each layer the best, from the qualitative and quantitative point of view.

Detailed field investigations were carried out for accomplishing our objective. For geological investigations, the rock mass was divided into homogenous regions representing the layer of Lutetian limestone and recent quaternary deposits, and the phosphate layer [5]. Characterizations were realized in 3 outcrops P1, P2 (for the complexity of the Lutetian limestone layer) and P3 (phosphate layer).

With regard to laboratory tests, uniaxial compressive strength, direct shear, and Brazilian tensile strength tests were performed for the three layers.

Classification of the rock mass. The slope mass rating (SMR) proposed by Romana (1985) [6] is obtained from the basic $R M R$ by adding a product of adjustment factors depending on the joint-slope relationship and adding a factor depending on the excavation method

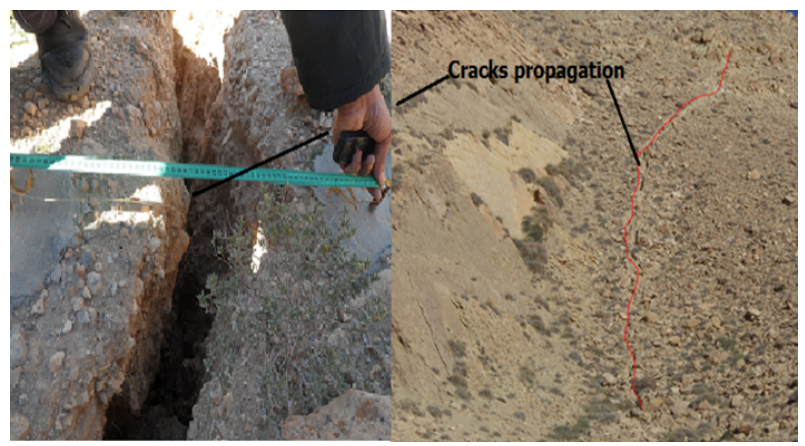

Fig. 3. Cracks propagation in Northwest flank of Kef Essenoun 
ONK-SC2 A

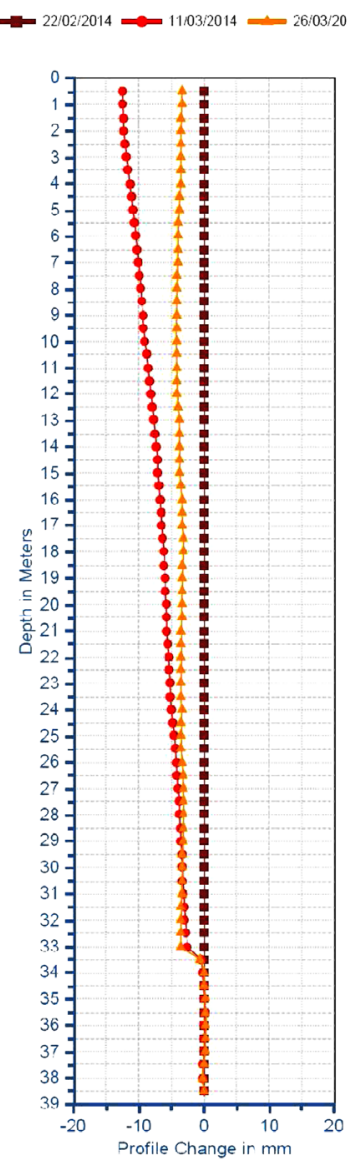

Fig. 4. Inclinometer profiles

$$
S M R=R M R_{\text {basic }}+\left(F_{1} \cdot F_{2} \cdot F_{3}\right)+F_{4},
$$

where $R M R_{\text {basic }}$ is Rock Mass Rating basic [5], based on the summation of 5 parameters in order to produce a final rating and whose parameters are:

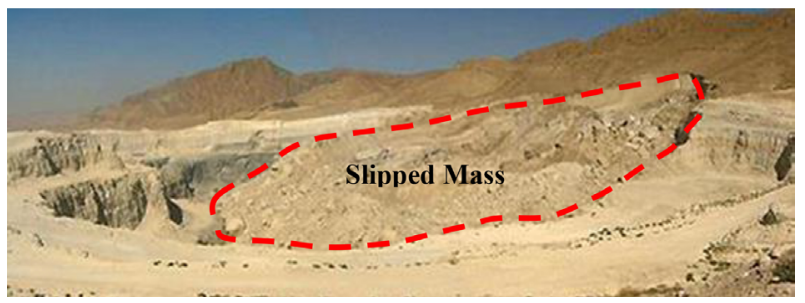

Fig. 5. Landslide of 2007
- the unconfined compressive strength of intact rock $\left(A_{i}\right)$;

- rock Quality Designation (RQD) $\left(A_{2}\right)$;

- the spacing of discontinuities $\left(A_{3}\right)$;

- the condition of discontinuities $\left(A_{4}\right)$;

- groundwater conditions $\left(A_{5}\right)$;

$F_{1}, F_{2}$, and $F_{3}$ are adjustment factors.

$F_{1}$, established empirically depends on the parallelism between the directions of the joints and the slopes.

$$
F_{1}=(1-\sin A)^{2},
$$

where $A$ is the angle between the directions of the joints and the slope.

$F_{2}$ depends on the dip of the joints for the plane rupture mode

$$
F_{2}=\operatorname{tg}^{2} \beta j,
$$

where $\beta j$ is the dip of the joints.

$F_{3}$ is related to the relationship between the slope of the embankment and the dip of the joints. $F_{4}$ takes into account the excavation method

The output results of $S M R$ and $R M R$ classification are shown in Table 1.

The results show that the layers of limestone and phosphate are stable with respect to the orientation of the slope whereas the marl layer is totally unstable. According to $S M R$ classification, the probability of a planar failure is $90 \%$.

Geotechnical model. The assembly of all the data collected through the different models (geological, structural, hydrogeological and rock mass) for each layer allows the generation of a reliable geotechnical model for the verification. The GSI is calculated by the relationship proposed by Hoek [15]

$$
G S I=1.5 * \text { Jcond }_{89}+R Q D / 2,
$$

where $J_{\text {cond }}{ }_{89}$ or $\left(A_{4}\right)$ is the joint condition rating defined by Bieniawski [5].

The GSI values are presented in Table 2.

Generalized Hoek-Brown criterion (GHB). The generalized Hoek and Brown strength criterion was used [12]. The expression of this criterion is

$$
\sigma_{1}=\sigma_{3}+\sigma_{c i}\left(m_{b} \frac{\sigma_{3}}{\sigma_{c i}}+s\right)^{a},
$$

where $\sigma_{1}$ and $\sigma_{3}$ are respectively the effective major and minor principal stresses of the rock mass at failure; $m_{b}, s$ and $a$ are the $G H B$ input parameters depending on the fracturing degree of the rock mass and can be estimated from the GSI, the disturbance factor $D$, and the material constant of intact rock mi, given (compressive stress is taken to be positive); $\sigma_{c i}$ is the uniaxial compressive strength of the intact rock.

\begin{tabular}{|c|c|c|c|c|c|c|c|c|c|c|c|c|c|}
\hline \multicolumn{14}{|c|}{$R M R$ Classification value } \\
\hline $\begin{array}{l}\text { Position } \\
\mathrm{N}^{\circ}\end{array}$ & \multicolumn{2}{|c|}{ Rock type } & \multicolumn{3}{|c|}{$\begin{array}{l}\text { The unconfined compressive } \\
\text { strength of intact rock }\end{array}$} & RQD & \multicolumn{2}{|c|}{ Joint spacing } & $\begin{array}{c}\text { Joint } \\
\text { condition }\end{array}$ & \multicolumn{2}{|c|}{$\begin{array}{l}\text { Groundwater } \\
\text { condition }\end{array}$} & \multicolumn{2}{|c|}{ RMR basic } \\
\hline P1 & \multicolumn{2}{|c|}{ Limestone } & \multicolumn{3}{|c|}{4} & 13 & \multicolumn{2}{|c|}{15} & 25 & \multicolumn{2}{|c|}{15} & \multicolumn{2}{|r|}{72} \\
\hline P2 & \multicolumn{2}{|c|}{ Phosphate } & \multicolumn{3}{|c|}{2} & 17 & \multicolumn{2}{|c|}{15} & 20 & \multicolumn{2}{|c|}{15} & \multirow{2}{*}{\multicolumn{2}{|c|}{$\begin{array}{l}69 \\
43\end{array}$}} \\
\hline P3 & $\mathrm{Ma}$ & & & & & 8 & & 8 & 10 & & & & \\
\hline \multicolumn{14}{|c|}{ SMR Classification value } \\
\hline & Rock type & $R M R$ & Dip direction & Dip & \multicolumn{3}{|c|}{ Dip direction of the slope } & Dip of slope & $F_{1}$ & $F_{2}$ & $F_{3}$ & $F_{4}$ & SMR \\
\hline & Limestone & 72 & 95 & 75 & \multicolumn{3}{|c|}{160} & \multirow{2}{*}{70} & 0.15 & 1 & -6 & 0 & 71 \\
\hline & Phosphate & 69 & 70 & 65 & \multicolumn{3}{|c|}{160} & & 0.15 & 1 & -25 & 0 & 65 \\
\hline & Marl & 43 & 145 & 60 & \multicolumn{3}{|c|}{160} & \multicolumn{2}{|r|}{0.7} & 1 & -60 & 0 & 1 \\
\hline
\end{tabular}

$$
m_{b}=m_{i} \exp \left(\frac{G S I-100}{28-14 D}\right)
$$

The Rock Mass Rating (RMR) and Slope Mass Rating (SMR) classification values 
The Geological Strength Index (GSI) values

\begin{tabular}{|l|c|c|}
\hline \multicolumn{1}{|c|}{ Rock type } & $R Q D$ & GSI \\
\hline Limestone & 70 & 72.5 \\
\hline Phosphate & 76 & 68 \\
\hline Marl & 40 & 35 \\
\hline
\end{tabular}

$$
\begin{gathered}
s=\exp \left(\frac{G S I-100}{9-3 D}\right) \\
a=\frac{1}{2}+\frac{1}{6}\left[\exp \left(-\frac{G S I}{15}\right)-\exp \left(-\frac{20}{3}\right)\right] .
\end{gathered}
$$

The advantages of $G H B$ criterion are [12]:

- it is non-linear in form, which agrees with experimental data over a range of confining stresses;

- it was developed through an extensive evaluation of laboratory test data covering a wide range of intact rock types;

- it provides a straightforward empirical means to estimate rock mass properties;

- there is almost three decades' worth of experience with its use by practitioners on a variety of rock engineering projects.

All parameters required in the geotechnical model based on the generalized Hoek-Brown criterion were calculated by the RocLab software and are summarized in Table 3.

Risk evaluation. This evaluation will be based on the comparison of the safety factors calculated by the methods of two different approaches: Limit Equilibrium Analysis and numerical methods through the finite difference method (FDM). In this work, the acceptance criteria from the safety factors will be established as follows: under static loadings, FOS must be greater than 1.2 in short-term stability and greater than 1.35 in long-term stability; under pseudo-static loadings, FOS must be greater than 1.1

Slope stability by Limit Equilibrium Analysis. The Limit Equilibrium Analysis (LEA) permits determining the safety factor of the slope based on the limit equilibrium plastic concept. LEA uses representative geometry, material and/or joint shear strength, material unit weights, groundwater, and external loading/support conditions to determine slope safety factors based on a set of simplifying mechanical assumptions [16]. The hypothesis of plane sliding along the layer of marls was considered by the choice of two surfaces crossing the marl layer (Fig. 6).

The simplified and extended Janbu's (1954-1973), and GLE/Morgenstern \& Price methods were chosen and tension crack in the top of the slope was taken into account.

Calculations were performed using software SLIDE [17].

The results obtained after calculations in both cases and through all the calculation methods used showed that the slope is in a critical state and that the choice of the marl layer as slip surface turned out to be logical and confirms the results obtained by other approaches. Different factors of safety values are presented in Table 4.

Slope stability by Finite Difference Method (FDM). The Finite Difference Method is a very efficient numerical method used in slope design. Like the finite element method (FEM), FDM uses the Shear Strength Reduction Method (SSR) [18]. The safety factor of a slope can be computed by reducing the shear strength of the rock in steps until the slope fails. The failure surface is determined by the strain and stress field.

In our case, the stability study is carried out by FLAC software [19] which is a continuum code that assumes the material is continuous and divides the rock mass into elements. Each element is assigned by a material model and material properties (Fig. 7). The mesh density was fine.

The results obtained by FLAC give a factor of safety FOS = $=1.20$, which indicates a critical, state in short-term under static loadings. The failure surface established by the SSR method indicates that the initialization of the movement was triggered with the continuous propagation of cracks located at the escarpment (Fig. 8).

The FDM also shows that the instability of the slope is due to the layer of marl.

The comparison of the different security factors obtained under static loadings by two different approaches indicates that

Table 3

\begin{tabular}{|c|c|c|c|c|}
\hline & \multirow{2}{*}{ Parameters } & \multicolumn{3}{|c|}{ Layers } \\
\hline & & Limestone & Phosphate & Marl \\
\hline \multirow{4}{*}{$\begin{array}{l}\text { Hoek Brown } \\
\text { Classification }\end{array}$} & $s_{c i}$ & $50 \mathrm{MPa}$ & $13 \mathrm{MPa}$ & $10.2 \mathrm{MPa}$ \\
\hline & GSI & 72 & 68 & 35 \\
\hline & $m_{i}$ & 9 & 8 & 7 \\
\hline & $D$ & 1 & 1 & 1 \\
\hline \multirow{3}{*}{$\begin{array}{l}\text { Hoek Brown } \\
\text { Criterion }\end{array}$} & $m_{b}$ & 1.21802 & 0.813611 & 0.067411 \\
\hline & $s$ & 0.00940356 & 0.00482795 & $1.97 \mathrm{E}-05$ \\
\hline & $a$ & 0.50116 & 0.501579 & 0.51595 \\
\hline \multirow{4}{*}{$\begin{array}{l}\text { Failure Envelope } \\
\text { Range }\end{array}$} & Application & Slopes & Slopes & Slopes \\
\hline & $\mathrm{s}_{3 \max }$ & $1.88411 \mathrm{MPa}$ & $1.46268 \mathrm{MPa}$ & $1.15856 \mathrm{MPa}$ \\
\hline & Unit Weight & $0.026 \mathrm{MN} / \mathrm{m}^{3}$ & $0.023 \mathrm{MN} / \mathrm{m}^{3}$ & $0.021 \mathrm{MN} / \mathrm{m}^{3}$ \\
\hline & Slope Height & $90 \mathrm{~m}$ & $90 \mathrm{~m}$ & $90 \mathrm{~m}$ \\
\hline \multirow{2}{*}{$\begin{array}{l}\text { Mohr-Coulomb } \\
\text { Fit }\end{array}$} & $c$ & $1.03928 \mathrm{MPa}$ & $0.349295 \mathrm{MPa}$ & $0.0842331 \mathrm{MPa}$ \\
\hline & $\varphi$ & 42.3732 degrees & 30.7468 degrees & 12.9528 degrees \\
\hline \multirow{4}{*}{$\begin{array}{l}\text { Rock Mass } \\
\text { Parameters }\end{array}$} & $s_{t}$ & $-0.386019 \mathrm{MPa}$ & $-0.0771417 \mathrm{MPa}$ & $-0.00298547 \mathrm{MPa}$ \\
\hline & $s_{c}$ & $4.82243 \mathrm{MPa}$ & $0.895711 \mathrm{MPa}$ & $0.038118 \mathrm{MPa}$ \\
\hline & $s_{c m}$ & $8.10498 \mathrm{MPa}$ & $1.6803 \mathrm{MPa}$ & $0.316277 \mathrm{MPa}$ \\
\hline & $E_{r m}$ & $2833.43 \mathrm{MPa}$ & $2316.41 \mathrm{MPa}$ & $394.03 \mathrm{MPa}$ \\
\hline
\end{tabular}

Geotechnical model parameters associated to the Hoek Brown Criterion 


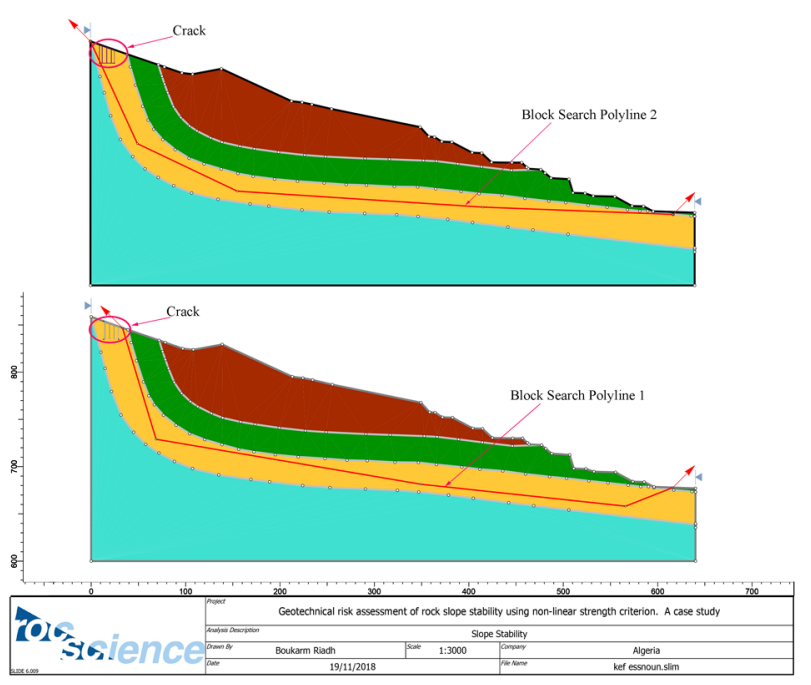

Fig. 6. Profile of Kef Essenoun for LEM calculation SLIDE

Table 4

Computed factor of safety from SLIDE

\begin{tabular}{|l|c|c|}
\hline \multirow{2}{*}{ Methods } & \multicolumn{2}{|c|}{ Safety factors } \\
\cline { 2 - 3 } & $\begin{array}{c}\text { FOS (Search } \\
\text { block polyline 1) }\end{array}$ & $\begin{array}{c}\text { FOS (Search } \\
\text { block polyline 2) }\end{array}$ \\
\hline Janbu's method 1954 & 1.082 & 1.095 \\
\hline Extended Janbu's method 1973 & 1.147 & 1.165 \\
\hline $\begin{array}{l}\text { GLE/Morgenstern and Price's } \\
\text { method }\end{array}$ & 1.139 & 1.172 \\
\hline
\end{tabular}

the state of the quarry is critical in the short term and could lead to high risks in the long term especially in dynamic loadings.

The extended Janbu's method 1973 and GLE/Morgenstern and Price's method for slip surface 2 gave safety factors

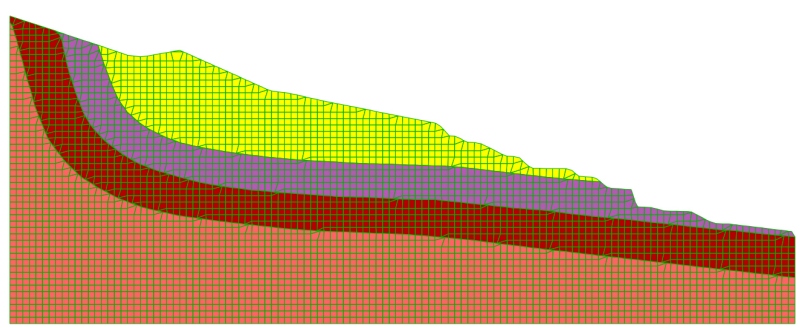

Fig. 7. Model of Kef Essenoun built by FLAC with fine meshing

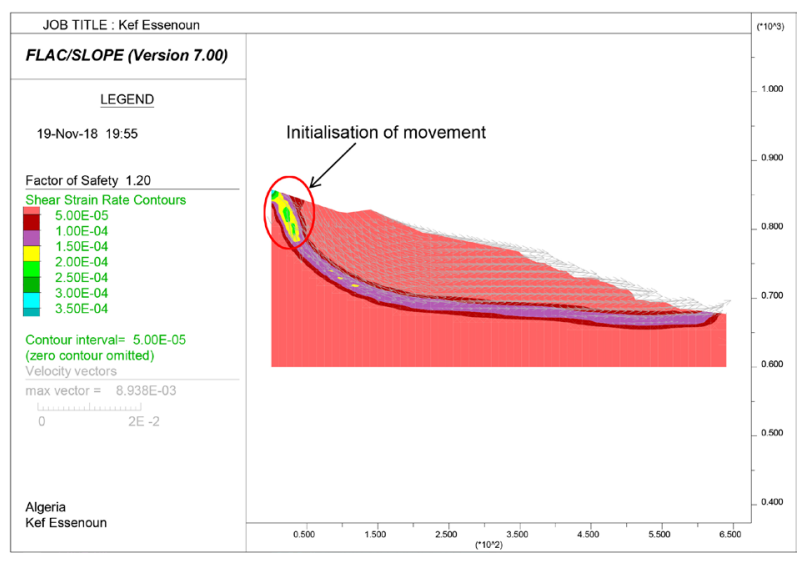

Fig. 8. Calculation of the safety factor and initialization of sliding movement by the Finite Difference Method quite similar to that of the method of SSR technique. This shows that the prior choice of the sliding surface fits well with the reality.

Through the observations on site and all the evaluations made, we can conclude that the cracks observed are the result of the tensile state following the slip of 2007 and that the mode of exploitation from bottom to top which is in contradiction with mining art has also contributed to their spread (not to mention the dynamic loadings).

From geotechnical point of view despite the economic challenges, the exploitation of this part of the mine must be suspended.

Conclusions. This study attempts to assess the geotechnical risk associated with Kef Essenoun open pit. Risk management allowed us to draw the following conclusions:

1. Control and monitoring are crucial to monitor the progress of work and predict instabilities especially for large-scale projects.

2. The classification of the rock masses can give a quantitative aspect to the collected observations and therefore estimate the stability status of the rock mass in advance.

3. The construction of the geotechnical model is a very important step where all the data related to the geology of the site, the structural aspect, the hydrogeology and the rock mass itself, must be superimposed in a single unit qualitatively and quantitatively.

The non-linear model by Hoek-Brown can be used with some reliability in these stability studies.

Acknowledgments. The authors of this work thank the company SOMIPHOS Group and CERAD for their full collaboration and availability along our visit.

\section{References.}

1. Siddique, T., Alam, M. M., Mondal, M. E. A., \& Vishal, V. (2015). Slope mass rating and kinematic analysis of slopes along the national highway-58 near Jonk, Rishikesh, India, Journal of Rock Mechanics and Geotechnical Engineering. DOI: 10.1016/j.jrmge.2015.06.007.

2. Saranaathan, S.E., \& Kannan, M. (2017). SMR and Kinematic analysis for slope instability along Bodi-Bodimettu ghat section, Tamil Nadu. Journal of the Geological Society of India, 89(5), 589-599. DOI: 10.1007/s12594-017-0648-1.

3. Faramarzi, L., Zare, M., Azhari, A., \& Tabaei, M. (2016). Assessment of rock slope stability at Cham-Shir Dam Power Plant pit using the limit equilibrium method and numerical modeling. Bull. Eng. Geol. Environ. DOI: 10.1007/s10064016-0870-x.

4. Pantelidis, L. (2009). Rock slope stability assessment through rock mass classification systems. International Journal of Rock Mechanics \& Mining Sciences, 46, 315-325. DOI: 10.1016/j.ijrmms.2008.06.003.

5. Bhawani Singh, \& Goel, R.K. (1999). Rock Mass Rating (RMR). In Rock Mass Classification ( $1^{\text {st }}$ ed., pp 34-46). Elsevier Science Ltd. DOI: 10.1016/B978-008043013-3/50006-7.

6. Bhawani Singh, \& Goel, R.K. (1999). Slope Mass Rating (SMR). In Rock Mass Classification ( $1^{\text {st }}$ ed., pp 171-183). Elsevier Science Ltd. DOI: 10.1016/B978-008043013-3/50017-1.

7. Bhawani Singh, Goel, R.K. (1999). Geological Strength Index (GSI). In Rock Mass Classification (1 ${ }^{\text {st }}$ ed., pp 242-249). Elsevier Science Ltd. DOI: 10.1016/B978-0080430133/50025-0.

8. Basahel, H., \& Mitri, H. (2017). Application of rock mass classification systems to rock slope stability assessment: A case study. Journal of Rock Mechanics and Geotechnical Engineering, 9(6), 993-1009. DOI: 10.1016/j.jrmge.2017.07.007.

9. Duncan C. Wyllie. (2018). Rock slope engineering: civil applications $\left(5^{\text {th }}\right.$ ed.). Boca Raton: CRC Press. DOI: $10.4324 / 9781315154039$.

10. Fredj, M., Hafsaoui, A., Khadri, Y., \& Boukarm, R. (2018). Influence of the failure surface choice on the safety factor value during slope stability studies. Naukovyi Visnyk 
Natsionalnoho Hirnychoho Universytetu, 3, 30-35. DOI: 10.29202/nvngu/2018-3/3.

11. Ureel, S., \& Momayez, M. (2014). An Investigation of the Limit Equilibrium Method and Numerical Modeling for Rock Slope Stability Analysis. In Conference: ASCE. At: Shanghai, China. DOI: 10.1061/9780784413395.025.

12. Eberhardt, E. (2012). The Hoek-Brown failure criterion. Rock Mechanics and Rock Engineering, 45(6), 981-988. DOI: 10.1007/s00603-012-0276-4.

13. Nouioua, I., Fehdi, C., Boubaya, D., Serhane, B., \& Djellali, A. (2015). Mapping underground cracks using 2D electrical resistivity tomography: the case of the landslide of Kef Essenoun phosphate deposit, Djebel El-Onk (northeast of Algeria). Arab J Geosci. DOI: 10.1007/s12517-014-1769-0.

14. Gadri, L., Hadji, R., Zahri, F., Benghazi, Z., Boumezbeur, A., Laid, B. M., \& Raïs, K. (2015). The quarries edge stability in opencast mines: a case study of the Jebel Onk phosphate mine, NE Algeria. Arabian Journal of Geosciences, 8(11), 8987-8997. DOI: 10.1007/s12517-015-1887-3.

15. Hoek, E., Carter, T.G., \& Diederichs, M.S. (2013). Quantification of the geological strength index chart. In: 47 ${ }^{h}$ US Rock Mech. Geomech. Symp, San Francisco, CA, USA June 23-26.

16. Read, J., \& Stacy, P. (2009). Guidelines for Open Pit Slope Design. CRC Press. ISBN: 978-0415874410.

17. Rocscience (2010). Slide 6.0: stability analysis for soil and rock slopes. Rocscience, Toronto.

18. Diederichs, M.S., Lato, M., Hammah, R., \& Quinn, P. (2007). Shear Strength Reduction (SSR) approach for slope stability analyses. In Rock Mechanics Meeting Society's Challenges, and Demands. Proceedings of the 1st Canada-US rock mechanics symposium. Vancouver, Canada, 27-31 May 2007, Taylor \& Francis Group, London, UK. DOI: 10.1201/ NOE0415444019.

19. FLAC: Itasca (2011). FLAC/Slope. I. Itasca Consulting Group. Minneapolis, Minnesota 55401 USA.

\section{Геотехнічна оцінка ризику стійкості схилу порід з використанням нелінійного критерію міцності}

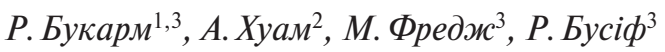

1 - Лабораторія цивільного будівництва та архітектури (ЛЦБА), факультет технічних наук, Університет Беджаі, м. Беджая, Алжир, e-mail: boulkram@gmail.com

2 - Університет Короля Халіда, Інженерний коледж, кафедра цивільних будівельних робіт, Гурайгер, м. Абха, Королівство Саудівської Аравії

3 - Кафедра гірничої справи та геології, факультет технічних наук, Університет Беджаі, м. Беджая, Алжир

Мета. Здійснити геотехнічну оцінку ризику стійкості породного укосу за допомогою емпіричного та чисельного методів, а також методу граничної рівноваги з узагальненим критерієм Хоека-Брауна як критерію оцінки руйнування, щоб охопити всі структурні та геомеханічні параметри, що впливають на стабільність відкритих ухилів.

Методика. У дослідженні проведена оцінка ризику у три етапи: визначення ризиків, аналіз ризиків і їх оцінка. Перш за все, спостереження за ділянкою й відстеження руху підтвердили дійсне існування ризику нестабільності. Потім за результатами локальних і лабораторних досліджень були отримані емпірична класифікація під назвою „Масова швидкість ухилу“ (МШУ) і геотехнічна модель. На закінчення була проведена кількісна оцінка ризику із застосуванням методу граничної рівноваги (МГР) і методу скінченних різниць (МСР) з урахуванням нелінійного критерію Хоека-Брауна в якості критерію руйнування.
Результати. Нелінійний критерій Хоека-Брауна може бути використаний з певним ступенем надійності в даному дослідженні стабільності, оскільки він ураховує порушення цілісності та швидкість утворення розривів у породній масі.

Наукова новизна. Полягає у використанні методу управління геотехнічними ризиками, заснованому на при-трансформаційних змінах різних підходів до кількісної оцінки геотехнічних ризиків, що виникають при розробці цього кар'єра. Для досягнення мети були задіяні: класифікація породних мас, геологічний індекс міцності, аналіз граничної рівноваги. Основні поняття дослідження мають на увазі об'єднання геометричних, структурних і механічних параметрів задля оцінки стабільності ухилів порід.

Практична значимість. Дана робота дозволила прийти до висновку про те, що класифікація МШУ може бути використана в якості попередньої перевірки, беручи до уваги структурні й геометричні особливості породних мас (умови орієнтації та порушення цілісності, швидкість утворення розривів). Значення коефіцієнта стійкості модифікованого методу Жанбу та методу Моргенштерна й Прайса досить близькі до методу скінченних різниць (застосування методу зменшення зображення межі міцності на зрушення).

Ключові слова: класифікація породних мас, показник міцності порід, геологічний індекс міцності, узагальнена модель Хоека-Брауна, коефіцієнт стійкості

\section{Геотехническая оценка риска устойчивости склона пород с использованием нелинейного критерия прочности}

\footnotetext{
Р. Букарм ${ }^{1,3}$, А. Хуам ${ }^{2}$, М. Фредж ${ }^{3}$, Р. Буси $\phi^{3}$

1 - Лаборатория гражданского строительства и архитектуры (ЛГСА), факультет технических наук, Университет Беджаи, г. Беджая, Алжир, e-mail: boulkram@gmail.com 2 - Университет Короля Халида, Инженерный колледж, кафедра гражданских строительных работ, Гурайгер, г. Абха, Королевство Саудовской Аравии

3 - Кафедра горного дела и геологии, факультет технических наук, Университет Беджаи, г. Беджая, Алжир
}

Цель. Осуществить геотехническую оценку риска устойчивости породного откоса с помощью эмпирического и численного методов, а также метода предельного равновесия с обобщенным критерием Хоека-Брауна как критерия оценки разрушения, чтобы охватить все структурные и геомеханические параметры, влияющие на стабильность открытых уклонов.

Методика. В исследовании проведена оценка риска в три этапа: определения рисков, анализ рисков и их оценка. Прежде всего, наблюдение за участком и отслеживание движения подтвердили действительное существование риска нестабильности. Затем по результатам локальных и лабораторных исследований были получены эмпирическая классификация под названием „Массовая скорость уклона“ (МСУ) и геотехническая модель. В заключение была произведена количественная оценка риска с применением метода предельного равновесия (МПР) и метода конечных разностей (МКР) с учетом нелинейного критерия Хоека-Брауна в качестве критерия разрушения.

Результаты. Нелинейный критерий Хоека-Брауна может быть использован с определенной степенью надежности в данном исследовании стабильности, поскольку он учитывает нарушение целостности и скорость образования разрывов в породной массе.

Научная новизна. Состоит в использовании метода управления геотехническими рисками, основанном на 
применении различных подходов к количественной оценке геотехнических рисков, возникающих при разработке этого карьера. Для достижения цели были задействованы: классификация породных масс, геологический индекс прочности, анализ предельного равновесия. Основные понятия исследования подразумевают объединение геометрических, структурных и механических параметров для оценки стабильности уклонов пород.

Практическая значимость. Данная работа позволила прийти к выводу о том, что классификация МСУ может быть использована в качестве предварительной проверки, принимая во внимание структурные и геометрические особенности породных масс (условия ориентации и нарушения целостности, скорость образования разрывов). Значения коэффициента устойчивости модифицированного метода Жанбу и метода Моргенштерна и Прайса достаточно близки к методу конечных разностей (применение метода уменьшения изображения предела прочности на сдвиг).

Ключевые слова: классификация породных масс, показатель прочности пород, геологический индекс прочности, обобщенная модель Хоека-Брауна, коэффициент устойчивости

Рекомендовано до публікації Абдалла Хафсауі. Дата надходження рукопису 17.10.18. 